bioRxiv preprint doi: https://doi.org/10.1101/322180; this version posted May 19, 2018. The copyright holder for this preprint (which was not certified by peer review) is the author/funder, who has granted bioRxiv a license to display the preprint in perpetuity. It is made available under ACC-BY-ND 4.0 International license.

\title{
Custom hereditary breast cancer gene panel selectively amplifies target genes for reliable variant calling
}

Setor Amuzu ${ }^{1,5 *}$, Timothée Revil ${ }^{1,5 *}$, William D. Foulkes ${ }^{1,2,3,4}$, Jiannis Ragoussis ${ }^{1,5}$

${ }^{1}$ Department of Human Genetics, McGill University

${ }^{2}$ Lady Davis Institute, Segal Cancer Centre, Jewish General Hospital, Montreal

${ }^{3}$ Department of Medical Genetics, Research Institute of the McGill University Health Centre

${ }^{4}$ Departments of Oncology and Medicine, McGill University

${ }^{5}$ McGill University and Génome Québec Innovation Centre

*These authors contributed equally to this work

\section{Abstract}

Background: Target enrichment coupled with next generation sequencing provide high-throughput approaches for screening several genes of interest. These approaches facilitate screening a panel of genes for mutations associated with inherited breast cancer for research, diagnostic, and genetic counseling applications.

Objective: To evaluate the performance of our custom 13 gene breast cancer panel, based on singleplex PCR, developed by WaferGen BioSystems. The panel was evaluated using patientderived DNA samples, in terms of target enrichment efficiency, off-target enrichment, uniformity of target capture, effect of GC content of target regions on coverage depth, and concordance with validated variant calls.

Results: At least $90 \%$ of target sequence for each gene was captured at $30 x$ or greater. We evaluated uniformity of target capture across samples by calculating the percentage of samples with at least $90 \%$ of total target captured at $100 x$ or greater and found $92 \%$ (33/36 samples) uniformity for our panel. Off-target enrichment ranges between $7.2 \%$ and $22.3 \%$. We found perfect concordance between our custom panel and the Qiagen human breast cancer panel for functionally annotated variant calls in high read depth shared target regions. Altogether, there was agreement between the panels for 779 variants at 41 loci. We also confirmed 10 pathogenic mutations, initially discovered by Sanger sequencing, in the appropriate samples following target enrichment using our custom WaferGen panel.

Conclusion: Our custom hereditary breast cancer panel is sensitive to the desired target genes and facilitates deep sequencing for reliable variant calling.

Keywords: Target enrichment performance, inherited breast cancer, gene panels, genotype concordance, next generation sequencing (NGS) 


\section{Introduction}

Targeted sequencing of genomic regions of interest remains a viable way to study diseases with known genetic associations and could be routinely used in molecular diagnoses. It is cheaper, produces data that is more tractable, substantially faster to analyze, and more easily understood for functional interpretation compared to whole exome sequencing. Investigating a panel of multiple genes can inform clinicians and researchers of genetic variants that may be associated with breast cancer risk (Easton et al., 2015; Kurian et al., 2014; Walsh et al., 2010). Breast cancer is the most prevalent cancer among women, and one of the leading causes of cancer deaths among women. In 2013, 1.8 million women died from breast cancer worldwide (Global Burden of Disease Cancer Collaboration et al., 2015). A number of genes of varying penetrance have been associated with susceptibility to breast cancer (Michailidou et al., 2013; Rahman et al., 2007; Wooster et al., 1995). Breast cancer gene panel testing is now commercially available for molecular biology applications, with a variety of pre-designed and customizable panels on offer. In this study we evaluated a custom panel designed for the SmartChip approach by WaferGen Biosystems Inc. (now acquired by Takara Bio USA Holdings, Inc.). Although the SmartChip has been evaluated using DNA derived from cancer cell lines (De Wilde et al., 2014), to our knowledge an evaluation for its application in inherited breast cancer still needs to be presented. We designed our panel to capture the entire coding sequence of 13 genes frequently mutated in inherited breast cancer cases, representing a target of $150 \mathrm{~Kb}$ in total. Our panel includes nine established breast cancer susceptibility genes with high and moderate risk. For these genes (BRCA1, BRCA2, ATM, CHEK2, TP53, CDH1, STK11, PALB2, PTEN) association with breast cancer risk has been established, primarily, on protein truncating variants (Easton et al., 2015). Low risk or proposed breast cancer susceptibility genes $B R I P 1, R A D 51 C, R A D 51 D$, and PPM1D were also included in spite of their relatively low mutation rate in inherited breast cancer cases (Slavin et al., 2017). All but two (RAD51C, RAD51D) of the genes on our panel are captured in version 84 of the COSMIC cancer gene census list (Futreal et al., 2004). A summarized description of target genes for our panel is presented in Table 1.

\begin{tabular}{|l|l|l|l|l|l|}
\hline $\begin{array}{l}\text { Gene } \\
\text { symbol }\end{array}$ & Name & $\begin{array}{l}\text { Major associated } \\
\text { cancer risk }\end{array}$ & $\begin{array}{l}\text { Summary of } \\
\text { function }\end{array}$ & $\begin{array}{l}\text { Role in } \\
\text { cancer }\end{array}$ & $\begin{array}{l}\text { References } \\
\text { (PubMed IDs) }\end{array}$ \\
\hline ATM & $\begin{array}{l}\text { Ataxia } \\
\text { telangiectasia } \\
\text { mutated }\end{array}$ & $\begin{array}{l}\text { Breast, leukemia, } \\
\text { lymphoma }\end{array}$ & $\begin{array}{l}\text { DNA double- strand } \\
\text { break repair }\end{array}$ & TSG & $\begin{array}{l}15928302, \\
21787400, \\
16832357\end{array}$ \\
\hline BRCA1 & $\begin{array}{l}\text { Familial breast/ } \\
\text { ovarian cancer } \\
\text { gene 1 }\end{array}$ & Breast, ovarian & $\begin{array}{l}\text { Homologous } \\
\text { recombination DNA } \\
\text { repair, replication fork } \\
\text { repair }\end{array}$ & TSG & $\begin{array}{l}2270482, \\
7545954, \\
7939630\end{array}$ \\
\hline
\end{tabular}


bioRxiv preprint doi: https://doi.org/10.1101/322180; this version posted May 19, 2018 . The copyright holder for this preprint (which was

not certified by peer review) is the author/funder, who has granted bioRxiv a license to display the preprint in perpetuity. It is made available under aCC-BY-ND 4.0 International license.

\begin{tabular}{|c|c|c|c|c|c|}
\hline$B R C A 2$ & $\begin{array}{l}\text { Familial breast/ } \\
\text { ovarian cancer } \\
\text { gene } 2\end{array}$ & $\begin{array}{l}\text { Breast, ovarian, } \\
\text { pancreatic }\end{array}$ & $\begin{array}{l}\text { Homologous } \\
\text { recombination DNA } \\
\text { repair }\end{array}$ & TSG & $\begin{array}{l}8524414, \\
10433620, \\
8640235\end{array}$ \\
\hline$B R I P 1$ & $\begin{array}{l}\text { BRCA1 } \\
\text { interacting } \\
\text { protein C- } \\
\text { terminal } \\
\text { helicase } 1\end{array}$ & Breast & $\begin{array}{l}\text { Homologous } \\
\text { recombination DNA } \\
\text { repair }\end{array}$ & TSG & $\begin{array}{l}16959974, \\
17033622\end{array}$ \\
\hline $\mathrm{CDH} 1$ & $\begin{array}{l}\text { Cadherin 1, type } \\
1, \text { E-cadherin } \\
\text { (epithelial) }\end{array}$ & Breast, gastric & $\begin{array}{l}\text { Calcium- dependent } \\
\text { cell adhesion } \\
\text { receptor }\end{array}$ & TSG & $\begin{array}{l}17660459, \\
7961105\end{array}$ \\
\hline CHEK2 & $\begin{array}{l}\text { Checkpoint } \\
\text { Kinase } 2\end{array}$ & $\begin{array}{l}\text { Breast, thyroid, } \\
\text { prostate }\end{array}$ & $\begin{array}{l}\text { DNA double-strand } \\
\text { break repair }\end{array}$ & TSG & $\begin{array}{l}27751358, \\
16880452, \\
25583358, \\
12533788\end{array}$ \\
\hline PALB2 & $\begin{array}{l}\text { Partner and } \\
\text { localizer of } \\
\text { BRCA2 }\end{array}$ & $\begin{array}{l}\text { Breast, Wilms } \\
\text { tumor*, }^{*} \\
\text { medulloblastoma* }^{*}\end{array}$ & $\begin{array}{l}\text { Homologous } \\
\text { recombination DNA } \\
\text { repair }\end{array}$ & TSG & $\begin{array}{l}17200668, \\
19812674\end{array}$ \\
\hline PPM1D & $\begin{array}{l}\text { Protein } \\
\text { phosphatase, } \\
\mathrm{Mg}^{2+} / \mathrm{Mn}^{2+} \\
\text { dependent 1D }\end{array}$ & $\begin{array}{l}\text { Breast, ovarian, } \\
\text { glioma }\end{array}$ & $\begin{array}{l}\text { Negative regulator of } \\
\text { TP53 and CHEK2 }\end{array}$ & Oncogene & $\begin{array}{l}12021784, \\
23242139, \\
23649806\end{array}$ \\
\hline PTEN & $\begin{array}{l}\text { Phosphatase } \\
\text { and tensin } \\
\text { homolog gene }\end{array}$ & $\begin{array}{l}\text { Breast, prostate, } \\
\text { endometrial, lung }\end{array}$ & $\begin{array}{l}\text { Modulator of } \\
\text { PI3K/AKT pathway, } \\
\text { regulates p53 }\end{array}$ & $\begin{array}{l}\text { TSG, } \\
\text { oncogene }\end{array}$ & $\begin{array}{l}9439675 \\
9140396 \\
12620407\end{array}$ \\
\hline$R A D 51 C$ & $\begin{array}{l}\text { RAD51 paralog } \\
\text { C }\end{array}$ & Ovarian & $\begin{array}{l}\text { Homologous } \\
\text { recombination DNA } \\
\text { repair, genome } \\
\text { stability }\end{array}$ & TSG & 20400964 \\
\hline$R A D 51 D$ & $\begin{array}{l}\text { RAD51 paralog } \\
\text { D }\end{array}$ & Ovarian & $\begin{array}{l}\text { Homologous } \\
\text { recombination DNA } \\
\text { repair, genome } \\
\text { stability }\end{array}$ & TSG & $\begin{array}{l}22415235, \\
22652533, \\
28656019\end{array}$ \\
\hline STK11 & $\begin{array}{l}\text { Serine/threonine } \\
\text { kinase } 11 \text { gene }\end{array}$ & $\begin{array}{l}\text { Breast, ovarian, } \\
\text { testicular, } \\
\text { pancreatic }\end{array}$ & Regulates cell polarity & TSG & $\begin{array}{l}16707622, \\
10429654\end{array}$ \\
\hline TP53 & $\begin{array}{l}\text { Tumor protein } \\
\text { p53 }\end{array}$ & $\begin{array}{l}\text { Breast, glioma, } \\
\text { leukemia, lung, } \\
\text { and other } \\
\text { pediatric- and } \\
\text { adult-onset } \\
\text { cancers }\end{array}$ & $\begin{array}{l}\text { Coordinates cellular } \\
\text { response to DNA } \\
\text { damage, hypoxia, } \\
\text { and other stress } \\
\text { signals }\end{array}$ & $\begin{array}{l}\text { TSG, } \\
\text { oncogene }\end{array}$ & $\begin{array}{l}2052583, \\
11219776, \\
11879567, \\
10427138, \\
1656362\end{array}$ \\
\hline
\end{tabular}

Table 1. List of 13 target genes for our hereditary breast cancer panel and their associated cancer risks. TSG - tumor suppressor gene. *Risks mainly associated with biallelic pathogenic variants. 
bioRxiv preprint doi: https://doi.org/10.1101/322180; this version posted May 19, 2018. The copyright holder for this preprint (which was not certified by peer review) is the author/funder, who has granted bioRxiv a license to display the preprint in perpetuity. It is made available under ACC-BY-ND 4.0 International license.

PCR-based target enrichment (TE) is commonly used to discover novel variants in known breast cancer susceptibility genes or validate mutations such as single nucleotide polymorphisms (SNPs) and small insertions and deletions (indels). Singleplex PCR strategies have been found to detect mutations present at less than $5 \%$ frequency in tumor samples (Kozarewa et al., 2015). Our custom panel is based on WaferGen's Seq-Ready TM TE Custom DNA Panel. This panel relies on WaferGen's high-density SmartChip ${ }^{\mathrm{TM}}$ TE singleplex PCR technology to capture up to $2.5 \mathrm{Mb}$ of cumulative sequence using massively parallel singleplex PCR (WaferGen Press, 2015). Each target region is amplified in an individual PCR reaction in a single well on the chip. This design is intended to improve sensitivity and specificity, and reduce primer-primer interaction as well as other interference often associated with multiplex PCR. WaferGen expects this approach to enable more reliable variant calling and obviate the need for variant validation by Sanger sequencing, for example. They report $84 \%$ mutation validation rate, representing 21 out of 25 mutations, based on sequencing data from 8 genes in a study using 15 cancer cell lines (De Wilde et al., 2014). Mutations validated in this study include SNPs and indels. Additionally, primers are designed such that no known SNPs with population frequency greater than $0.5 \%$ are included in last 10 nucleotides on the 3 ' end of a primer, to minimize off-target hybridization and reduce risk of allelic dropouts (De Wilde et al., 2014). Amplicons are designed to span beyond target exons and overlap each other to increase the probability of capturing target regions (Figure 1).

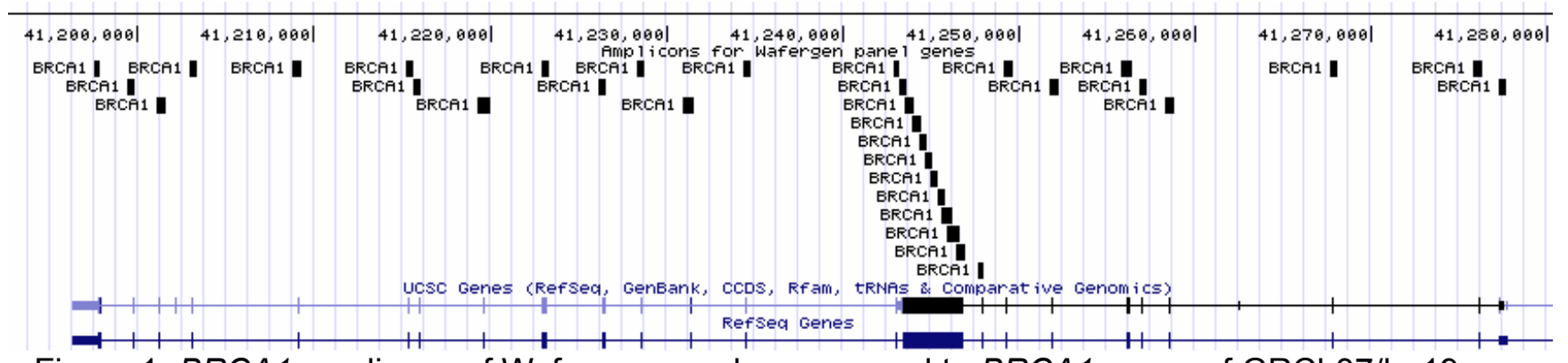

Figure 1. BRCA1 amplicons of Wafergen panel are mapped to BRCA1 exons of GRCh37/hg19 using UCSC genome browser (Kent et al., 2002). Amplicons overlap target exons to maximize capture. Amplicons are designed to span exon-intron boundaries and untranslated regions.

To develop our custom breast cancer panel, we provided WaferGen with coordinates of our genes of interest, desired amplicon length, sequencing platform, and samples. Genomic coordinates for our WaferGen panel is provided as Supplementary file 1. Our custom breast cancer panel targets 314 regions representing all exons for 13 genes which are listed, along with other panel features, in Table 2. 


\begin{tabular}{|c|c|c|c|c|}
\hline $\begin{array}{l}\text { Gene (RefSeq } \\
\text { accession) }\end{array}$ & Number of exons & $\begin{array}{l}\text { Number of } \\
\text { amplicons }\end{array}$ & $\begin{array}{l}\text { Exon target size } \\
\text { (bp) }\end{array}$ & Capture size (bp) \\
\hline $\begin{array}{l}\text { ATM } \\
(\text { NM_000051) }\end{array}$ & 63 & 72 & 13,210 & 32,303 \\
\hline $\begin{array}{l}\text { BRCA1 } \\
\text { (NM_007300) }\end{array}$ & 24 & 33 & 6,083 & 15,820 \\
\hline $\begin{array}{l}\text { BRCA2 } \\
\text { (NM_000059) }\end{array}$ & 27 & 42 & 11,002 & 21,744 \\
\hline $\begin{array}{l}\text { BRIP1 } \\
\text { (NM_032043) }\end{array}$ & 20 & 28 & 6,512 & 13,454 \\
\hline $\begin{array}{l}\text { CDH1 } \\
(\mathrm{NM} \text { 004360) }\end{array}$ & 16 & 21 & 4,831 & 9,712 \\
\hline $\begin{array}{l}\text { CHEK2 } \\
\text { (NM_001005735) }\end{array}$ & 16 & 16 & 2,003 & 8,109 \\
\hline $\begin{array}{l}\text { PALB2 } \\
\text { (NM_024675) }\end{array}$ & 13 & 18 & 4,071 & 8,255 \\
\hline $\begin{array}{l}\text { PPM1D } \\
\text { (NM_003620) }\end{array}$ & 6 & 10 & 3,040 & 4,553 \\
\hline $\begin{array}{l}\text { PTEN } \\
\text { (NM_000314) }\end{array}$ & 9 & 30 & 5,556 & 14,728 \\
\hline $\begin{array}{l}\text { RAD51C } \\
\text { (NM_058216) }\end{array}$ & 9 & 9 & 1,291 & 3,844 \\
\hline $\begin{array}{l}\text { RAD51D } \\
\text { (NM_002878) }\end{array}$ & 10 & 9 & 1,461 & 4,448 \\
\hline $\begin{array}{l}\text { STK11 } \\
\text { (NM_000455) }\end{array}$ & 10 & 15 & 3,286 & 7,596 \\
\hline $\begin{array}{l}\text { TP53 } \\
\text { (NM_001276760) }\end{array}$ & 11 & 11 & 2,602 & 6,079 \\
\hline Total & 234 & 314 & 64,948 & 150,645 \\
\hline
\end{tabular}

Table 2. Target genes of custom WaferGen hereditary breast cancer panel. Panel is based on Seq-Ready ${ }^{\text {TM }}$ TE MultiSample Custom DNA Panel (Part number: 440-000053) product line. Amplicon size ranges from 350 - 749 bases. Capture and exon coordinates are based on human reference genome assembly GRCh37/hg19.

In this study, our goals were to assess how well our custom panel captures its target genes, examine the effect of GC content of target regions on coverage depth, and measure concordance in genotype calls between our panel and known variant calls obtained from Sanger sequencing and target enrichment using the Qiagen human breast cancer panel. 
bioRxiv preprint doi: https://doi.org/10.1101/322180; this version posted May 19, 2018. The copyright holder for this preprint (which was not certified by peer review) is the author/funder, who has granted bioRxiv a license to display the preprint in perpetuity. It is made available under aCC-BY-ND 4.0 International license.

\section{Materials and Methods}

\section{Samples}

Peripheral blood samples from 36 hereditary breast cancer cases were selected for testing on our custom WaferGen breast cancer panel. A subset (19) of these samples were tested using the validation panel, Qiagen Human breast cancer panel. The Human Breast Cancer GeneRead DNAseq Gene Panel targets hotspots in 20 genes commonly mutated in human breast cancer samples using a multiplexed PCR assay. The Qiagen panel is compatible with both germline and tumor mutation profiling and shares a common target region with our custom panel. Genomic DNA (gDNA) was extracted from blood samples and quantified using Qubit dsDNA HS.

\section{Target enrichment and library preparation}

Purified genomic DNA from our Qiagen samples were subjected to target enrichment using the GeneRead DNAseq Targeted V2 Panel and the GeneRead DNAseq PCR Kit V2 (comprising oligonucleotides, enzymes and buffers) according to manufacturer's instructions. Wafergen's SmartChip target enrichment platform, previously described by De Wilde et al. (De Wilde et al., 2013), was used to amplify our custom genomic targets. Reaction mix for WaferGen samples was prepared using 350ng of gDNA and KAPA2G DNA polymerase. Reaction volume per well of SmartChip was 50nl. PCR was performed using a WaferGen-modified thermal cycler and resulting amplicons pooled by centrifugation.

Nextera XT tagmentation protocol was used to prepare the sequencing library from WaferGen amplicons while the ligation-based NEBNext method for Illumina was used to prepare the sequencing library from Qiagen amplicons. WaferGen amplicons, due to their size (350 - 749 bases), were fragmented prior to ligating read-specific sequencing primers, index, and adapter sequences. However, there was no fragmentation step in the library preparation for Qiagen samples because these amplicons are smaller (48 - 143 bases).

\section{Sequencing}

Samples were sequenced by the McGill University and Génome Québec Innovation Centre sequencing service. All samples were sequenced on the Illumina HiSeq 2500 to produce 150bp, paired-end reads. Samples were sequenced in rapid run mode.

\section{Data analysis}

Raw sequencing data was filtered using Trimmomatic (Bolger et al., 2014) with Phred Quality score of 20 as cutoff. Filtered sequence reads for each sample were aligned to human reference genome build GRCh37/hg19 using BWA-MEM (Li and Durbin, 2010). The alignment files were converted from SAM to BAM format and sorted. BEDtools (Quinlan and Hall, 2010), and bamstats05 from the 
Jvarkit (Pierre, 2015) package were used to determine breadth and depth of coverage metrics for individual target intervals using each sample's BAM file. Coverage metrics for samples were aggregated for each panel using custom R scripts. Plots and statistics were also generated using $\mathrm{R}$ programming language for statistical computing ( $\mathrm{R}$ Core Team, 2016). Variant calling was done using HaplotypeCaller of GATK version 3.7-0-gcfedb67 (McKenna et al., 2010), according to best practices. Variants for both sets of samples were called as a cohort. The resulting VCF file was annotated with dbSNP (Sherry et al., 2001) identifiers from dbSNP146 using SnpSift (Cingolani et al., 2012). Variants were normalized using bcftools, and partial genotypes were converted to complete genotypes using genotype likelihood scores. Annotated VCF was filtered with the vcfR (Knaus and Grunwald, 2016) package and custom R scripts. Variants were filtered using total coverage threshold of 30 . Only variants with dbSNP identifiers (rs IDs) were considered. For the Qiagen panel, only variants outside of the target enrichment primer regions were considered for assessment of concordance with our custom panel since variants near the amplicon boundaries can cause misalignments of multiple reads leading to false-positive or false-negative variant calls (Vijaya Satya et al., 2014). SnpSift Concordance was used to measure genotype concordance. Integrative Genomics Viewer (Thorvaldsdóttir et al., 2013) was used to manually inspect some variant calls. 
bioRxiv preprint doi: https://doi.org/10.1101/322180; this version posted May 19,2018 . The copyright holder for this preprint (which was not certified by peer review) is the author/funder, who has granted bioRxiv a license to display the preprint in perpetuity. It is made available under aCC-BY-ND 4.0 International license.

\section{Results and Discussion}

\section{Target Enrichment Efficiency}

Target capture was inferred from sequence reads, derived from target enrichment amplicons, that mapped to target genes. We defined coverage breadth as the proportion of unique reads that were unambiguously mapped to target regions, and determined coverage breadth per gene and per sample at coverage depth thresholds of 1x, 30x, 50x, and 100x. By examining breadth of coverage per gene and per sample we assessed the sensitivity of capture for each target gene, and uniformity of total target enrichment across samples. In Figure 2, we show that more than $90 \%$ of target sequence for each gene is captured at $30 x$ or greater. The majority of exons are captured at reasonable depth for germline variant calling.

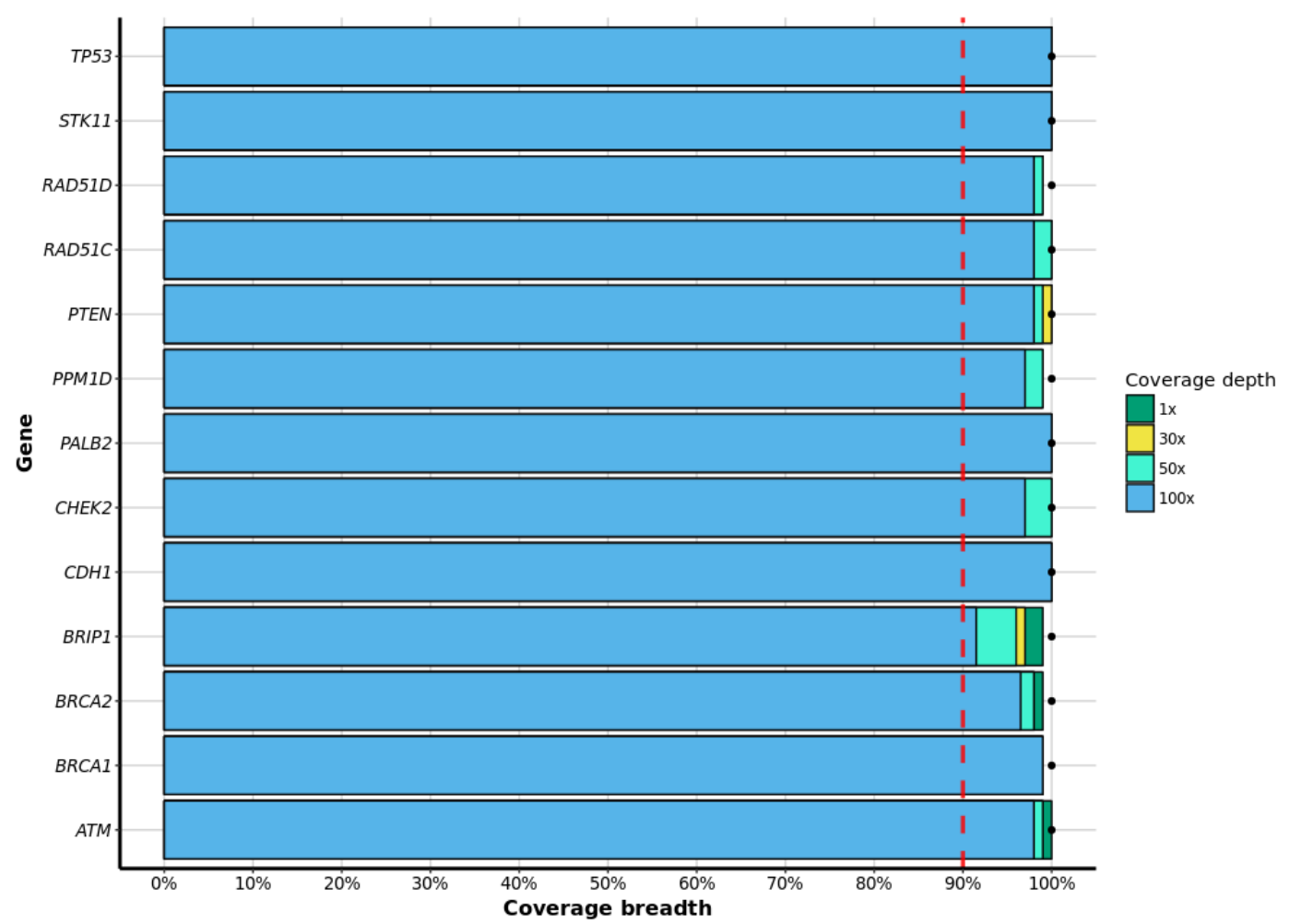

Figure 2. A barplot showing the median percentage of target genes captured at $1 \mathrm{x}, 30 \mathrm{x}, 50 \mathrm{x}$ and $100 x$ coverage depth thresholds. The red dashed line at $90 \%$ on the Coverage breadth axis represents our expected minimum breadth of coverage for each gene. The black dot beside each bar denotes the maximum breadth of coverage at $1 \mathrm{x}$ for a specific target gene.

Similarly, coverage depth for target exons across samples is also adequate for germline variant calling with $97 \%$ (35/36) of samples captured at least 30x (Figure 3). Uniformity of target capture across samples is high $-92 \%$ of samples (33/36) capture $90 \%$ of target with coverage depth of at least $100 x$. 


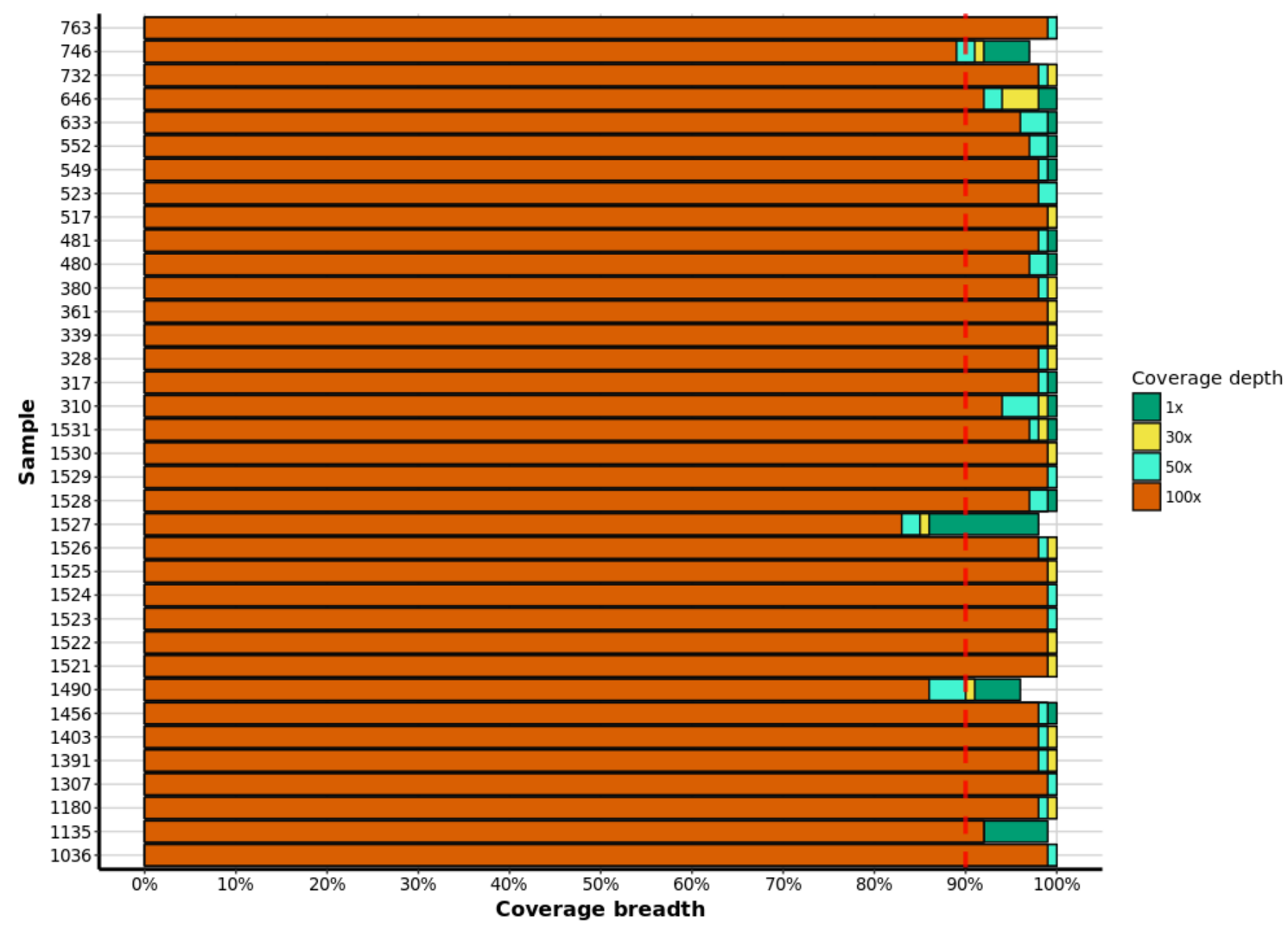

Figure 3. Median percentage of target exons captured for each sample at $1 \mathrm{x}, 30 \mathrm{x}, 50 \mathrm{x}$ and $100 \mathrm{x}$ coverage depth thresholds. The red dashed line at $90 \%$ on the Coverage breadth axis represents our minimum expected breadth of coverage for each sample.

We assessed the effect of GC content on coverage depth of amplicons. The Wafergen panel is capable of enriching high GC (>70\%) and low GC (<30\%) regions, but peak coverage depth lies between these extremes of GC as expected from Illumina sequencing (Figure 4). Coverage depth tends to increase with GC content. This is driven by the sharp increase in coverage depth from low GC (30\% - 40\%) amplicons to moderate GC (45\% - 65\%) amplicons, and does not represent overall increase in coverage depth across the entire spectrum $(26 \%-81 \%)$ of GC content of amplicons. 


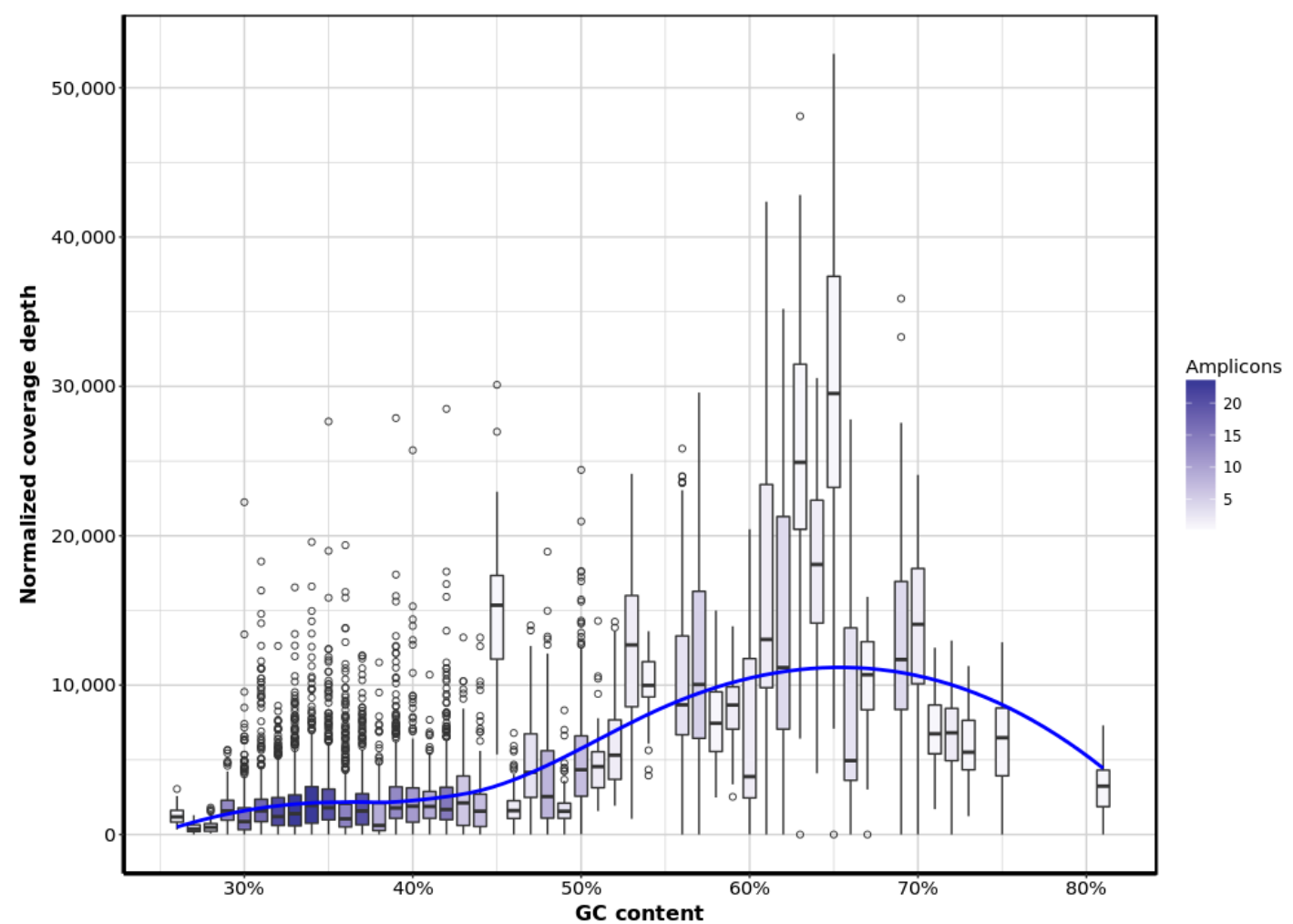

Figure 4. Relationship between GC content of amplicons and coverage depth. Normalized coverage depth is on-target reads per kilobase target region, million mapped reads and number of overlapping amplicons. Amplification of target occurs across the width of GC content $(26 \%-81 \%)$.

\section{Off-target enrichment}

We define off-target enrichment as the percentage of reads mapping to other regions of the genome outside the capture target per sample. We observed that off-target enrichment ranges between $7.2 \%$ and $22.3 \%$, with mean of $17.3 \%$ and standard deviation $3.7 \%$.

\section{Concordance in genotype calls}

Using sanger sequencing, 10 germline heterozygous, pathogenic mutations were identified for 10 WaferGen samples. These mutations were confirmed in the relevant samples with the same zygosity identified by Sanger sequencing (Table 3).

\begin{tabular}{|l|l|l|l|}
\hline Gene & Variant & dbSNP ID & Sample \\
\hline BRCA1 & c.68_69delAG (p.Glu23fs) & rs386833395 & 1521 \\
\hline BRCA2 & c.5857G>T (p.Glu1953*) & rs80358814 & 1522 \\
\hline TP53 & c.730G>A (p.Gly244Ser) & & 1523 \\
\hline ATM & c.2572T>C (p.Phe858Leu) & rs1800056 & 1524 \\
\hline
\end{tabular}




\begin{tabular}{|l|l|l|l|}
\hline PALB2 & c.229delT (p.Cys77fs) & rs180177084 & 1525 \\
\hline CHEK2 & c.1100delC (p.Thr367fs) & rs555607708 & 1526 \\
\hline STK11 & c.876delC (p.Tyr292fs) & & 1527 \\
\hline PTEN & c.389G>A (p.Arg130GIn) & rs121909229 & 1528 \\
\hline CDH1 & c.382delC (p.His128fs) & 1529 \\
\hline PPM1D & c.1654C>T (p.Arg552*) & & 1530 \\
\hline
\end{tabular}

Table 3. List of mutations validated by Sanger sequencing for 10 WaferGen samples. Mutations include SNPs and short deletions.

We also assessed concordance in genotype calls between our custom WaferGen panel and Qiagen's human breast cancer panel over a shared target region of $33 \mathrm{~Kb}$, comprising amplicons for TP53, ATM, BRCA1, BRCA2, PTEN, and CDH1. A subset of 19 samples were available for this assessment. We considered genotypes that were called with read depth of 30 or greater and variants that were recorded in dbSNP. In Table 4, we present the frequencies of genotypes that meet these conditions. We found perfect concordance between genotype calls for the Wafergen and Qiagen panels over a shared target region for the same samples at high confidence, annotated variant loci.

\begin{tabular}{|l|l|l|l|l|}
\hline \multirow{2}{*}{ Wafergen } & \multicolumn{3}{|c|}{ Qiagen } & Totals \\
\cline { 2 - 5 } & $0 / 0$ & $0 / 1$ & $1 / 1$ & \\
\hline $0 / 0$ & 581 & 0 & 0 & 581 \\
\hline $0 / 1$ & 0 & 127 & 0 & 127 \\
\hline $1 / 1$ & 0 & 0 & 71 & 71 \\
\hline Total & 581 & 127 & 71 & 779 \\
\hline
\end{tabular}

Table 3. Contigency table of genotype counts for 41 variant loci across 19 matching samples representing the relationship between genotype calls for WaferGen and Qiagen panels. 0/0 is homozygous reference, $0 / 1$ is heterozygous, and $1 / 1$ denotes homozygous alternate. 
bioRxiv preprint doi: https://doi.org/10.1101/322180; this version posted May 19, 2018. The copyright holder for this preprint (which was not certified by peer review) is the author/funder, who has granted bioRxiv a license to display the preprint in perpetuity. It is made available under aCC-BY-ND 4.0 International license.

\section{Conclusions}

We demonstrated that our custom hereditary breast cancer panel adequately captures all exons of 13 breast cancer susceptibility genes for next generation sequencing and subsequent detection of germline mutations associated with breast cancer. The WaferGen panel is sensitive for target genes with minimal off-target amplification. At least $90 \%$ of target region is captured at reasonable depth (at least 30x) for reliable variant calling, with uniform capture across samples. Additionally, our custom panel can confirm known pathogenic mutations, including SNPs and short deletions, and is comparable to more established Qiagen human breast cancer panel in terms of amplifying exome targets for high confidence variant calling.

\section{Author contributions}

WDF and JR conceived the study and critically revised the mauscript. WDF arranged the procurement of samples. JR coordinated sequencing and target enrichment. JR and WDF were involved in selecting genomic coordinates for the panel.

TR performed target enrichment, and data analysis (quality control, sequence alignment, and variant calling). TR also revised the manuscript.

SA performed data analysis (coverage analysis, variant concordance assessment) and visualization, and prepared the first draft of this manuscript.

\section{Acknowledgements}

We are grateful to Nelly Sabbaghian and Evan Weber for preparing samples.

\section{References}

Bolger, A. M., Lohse, M., and Usadel, B. (2014). Trimmomatic: a flexible trimmer for Illumina sequence data. Bioinformatics 30, 2114-20. doi:10.1093/bioinformatics/btu170.

Cingolani, P., Patel, V. M., Coon, M., Nguyen, T., Land, S. J., Ruden, D. M., et al. (2012). Using Drosophila melanogaster as a Model for Genotoxic Chemical Mutational Studies with a New Program, SnpSift. Front. Genet. 3, 35. doi:10.3389/fgene.2012.00035.

De Wilde, B., Lefever, S., Dong, W., Dunne, J., Husain, S., Derveaux, S., et al. (2014). Target enrichment using parallel nanoliter quantitative PCR amplification. BMC Genomics 15, 184. doi:10.1186/1471-2164-15-184.

De Wilde, B., Lefevre, S., Hellemans, J., Dong, W., Dunne, J., Husain, S., et al. (2013). Targetenrichment for Next-Generation Sequencing studies using the WaferGen SmartChip ( RealTime ) PCR System. Available at: 
bioRxiv preprint doi: https://doi.org/10.1101/322180; this version posted May 19, 2018. The copyright holder for this preprint (which was not certified by peer review) is the author/funder, who has granted bioRxiv a license to display the preprint in perpetuity. It is made available under aCC-BY-ND 4.0 International license.

http://content.stockpr.com/wafergen/db/224/1659/file/TargetEnrchmnt_NGS_WPf.pdf.

Easton, D. F., Pharoah, P. D. P., Antoniou, A. C., Tischkowitz, M., Tavtigian, S. V., Nathanson, K. L., et al. (2015). Gene-Panel Sequencing and the Prediction of Breast-Cancer Risk. N. Engl. J. Med. 372, 2243-2257. doi:10.1056/NEJMsr1501341.

Futreal, P. A., Coin, L., Marshall, M., Down, T., Hubbard, T., Wooster, R., et al. (2004). A census of human cancer genes. Nat. Rev. Cancer 4, 177-183. doi:10.1038/nrc1299.

Global Burden of Disease Cancer Collaboration, G. B. of D. C., Fitzmaurice, C., Dicker, D., Pain, A., Hamavid, H., Moradi-Lakeh, M., et al. (2015). The Global Burden of Cancer 2013. JAMA Oncol. 1, 505-27. doi:10.1001/jamaoncol.2015.0735.

Kent, W. J., Sugnet, C. W., Furey, T. S., Roskin, K. M., Pringle, T. H., Zahler, A. M., et al. (2002). The human genome browser at UCSC. Genome Res. 12, 996-1006. doi:10.1101/gr.229102.

Knaus, B. J., and Grunwald, N. J. (2016). VcfR: an R package to manipulate and visualize VCF format data. Cold Spring Harbor Labs Journals doi:10.1101/041277.

Kozarewa, I., Armisen, J., Gardner, A. F., Slatko, B. E., and Hendrickson, C. L. (2015). Overview of Target Enrichment Strategies. Curr. Protoc. Mol. Biol., 1-23. doi:10.1002/0471142727.mb0721s112.

Kurian, A. W., Hare, E. E., Mills, M. A., Kingham, K. E., McPherson, L., Whittemore, A. S., et al. (2014). Clinical evaluation of a multiple-gene sequencing panel for hereditary cancer risk assessment. J. Clin. Oncol. 32, 2001-9. doi:10.1200/JCO.2013.53.6607.

Li, H., and Durbin, R. (2010). Fast and accurate long-read alignment with Burrows-Wheeler transform. Bioinformatics 26, 589-95. doi:10.1093/bioinformatics/btp698.

McKenna, A., Hanna, M., Banks, E., Sivachenko, A., Cibulskis, K., Kernytsky, A., et al. (2010). The Genome Analysis Toolkit: a MapReduce framework for analyzing next-generation DNA sequencing data. Genome Res. 20, 1297-303. doi:10.1101/gr.107524.110.

Michailidou, K., Hall, P., Gonzalez-Neira, A., Ghoussaini, M., Dennis, J., Milne, R. L., et al. (2013). Large-scale genotyping identifies 41 new loci associated with breast cancer risk. Nat. Genet. 45, 353-361. doi:10.1038/ng.2563.

Pierre, L. (2015). JVarkit: java-based utilities for Bioinformatics. Figshare. Available at: https://dx.doi.org/10.6084/m9.figshare.1425030.v1 [Accessed July 26, 2016].

Quinlan, A. R., and Hall, I. M. (2010). BEDTools: A flexible suite of utilities for comparing genomic features. Bioinformatics 26, 841-842. doi:10.1093/bioinformatics/btq033.

R Core Team (2016). R: A Language and Environment for Statistical Computing. Available at: https://www.r-project.org/.

Rahman, N., Seal, S., Thompson, D., Kelly, P., Renwick, A., Elliott, A., et al. (2007). PALB2, which encodes a BRCA2-interacting protein, is a breast cancer susceptibility gene. Nat. Genet. 39, 165-167. doi:10.1038/ng1959.

Sherry, S. T., Ward, M., Kholodov, M., Baker, J., Phan, L., Smigielski, E. M., et al. (2001). dbSNP: the NCBI database of genetic variation. Nucleic Acids Res. 29.

Slavin, T. P., Maxwell, K. N., Lilyquist, J., Vijai, J., Neuhausen, S. L., Hart, S. N., et al. (2017). The 
contribution of pathogenic variants in breast cancer susceptibility genes to familial breast cancer risk. npj Breast Cancer 3, 22. doi:10.1038/s41523-017-0024-8.

Thorvaldsdóttir, H., Robinson, J. T., and Mesirov, J. P. (2013). Integrative Genomics Viewer (IGV): high-performance genomics data visualization and exploration. Brief. Bioinform. 14, 178-92. doi:10.1093/bib/bbs017.

Satya, R.V., DiCarlo, J., Mamanova, L., Coffey, A., Scott, C., Kozarewa, I., et al. (2014). Edge effects in calling variants from targeted amplicon sequencing. BMC Genomics 15, 1073. doi:10.1186/1471-2164-15-1073.

WaferGen Press (2015). Seq-Ready ${ }^{\text {TM }}$ TE MultiSample Custom DNA Panels Flexible Designs, Superior Coverage. Available at: http://content.stockpr.com/wafergen/db/224/1807/file/Seq_Ready_TE_MultiSample_Custom_ PB_2015_RevC_3_PRESS[1].pdf.

Walsh, T., Lee, M. K., Casadei, S., Thornton, A. M., Stray, S. M., Pennil, C., et al. (2010). Detection of inherited mutations for breast and ovarian cancer using genomic capture and massively parallel sequencing. Proc. Natl. Acad. Sci. U. S. A. 107, 12629-33.

doi:10.1073/pnas.1007983107.

Wooster, R., Bignell, G., Lancaster, J., Swift, S., Seal, S., Mangion, J., et al. (1995). Identification of the breast cancer susceptibility gene BRCA2. Nature 378, 789-792. doi:10.1038/378789a0. 